\title{
OS SENTIDOS E OS NÃO SENTIDOS DA LÍNGUA PORTUGUESA: QUESTÕES DE LÍNGUA E LINGUAGEM NOS CONTOS DE MIA COUTO
}

\author{
MEANING AND NO MEANING OF \\ PORTUGUESE LANGUAGE: ISSUES OF SPEECH \\ AND LANGUAGE IN MIA COUTO TALES
}

Maurício Silva ${ }^{1}$

\section{RESUMO}

O presente artigo trata da produção ficcional de Mia Couto, em especial seus contos, analisando o modo como o autor moçambicano trabalha em seus textos questões relacionadas à língua e à linguagem, além de vincularmos tais questões às teorias do pós-colonialismo. Para Mia Couto, o processo de colonização impõe ao colonizado um outro modo de falar, que corresponde a uma outra língua.

PALAVRAS-CHAVE: Mia Couto; Literatura africana lusófona; Língua Portuguesa.

\section{ABSTRACT}

This article is about the fictional production of Mia Couto, especially his short stories. It analyzes how the Mozambican author uses in his writings issues related to speech and language and links it to the theories of postcolonialism. For Mia Couto the process of colonization imposes on the colonized another way of speaking, which corresponds to another language.

KEYWORDS: Mia Couto; Lusophone African Literature; Portuguese. 


\section{INTRODUÇÃO}

A literatura africana de expressão lusófona, presente nos cinco países em que o português - transplantado, a princípio, como língua do colonizador - foi, finalmente, adotado como língua oficial, tem se revelado um campo particularmente rico em possibilidades de estudo e pesquisa, resultado de uma profícua produção estética e de um inesgotável universo de criação no âmbito do imaginário literário. Estudar, portanto, a produção ficcional de seus autores e autoras é compreender como se organiza, no espaço cultural lusoafricano, a concepção de mundo dos povos que ali vivem, bem como sua relação com a própria língua portuguesa, além de refazer o caminho histórico e cultural destas nações por meio de uma interação entre a literatura e a realidade local.

Analisando o desenvolvimento dessa produção literária, não há como negar - sobretudo se pensarmos na produção mais recente - nem sua procedência anticolonialista, no plano social e histórico, nem sua vinculação com os conceitos de nacionalismo e identidade. Com efeito, se essa literatura nasce vinculada a um projeto mais amplo de luta anticolonial, o que lhe confere, às vezes, um caráter de literatura militante, com o passar do tempo ela passa a se ligar a um desígnio identitário-nacionalista, resultando, primeiro, na afirmação da identidade cultural local, com a valorização das singularidades nativas e humanitárias da região; depois, na criação de uma consciência nacionalista, incentivando a defesa de valores sociais comunitários.

De modo sumário, pode-se afirmar, sobre a produção literária africana de expressão portuguesa, que ela pressupõe, como sugere Pires Laranjeira, uma variedade de atitudes estéticas (busca de autonomia, reivindicação anticolonial, afirmação nacional, assunção étnica e folclórica, uso do bilinguismo textual, exaltação rácica etc.) visceralmente vinculadas à constituição/afirmação da comunidade africana (LARANJEIRA, 2000). No contexto descrito, Mia Couto talvez seja o nome que melhor sintetize valores e promessas da produção literária da África lusófona na contemporaneidade, elevando essa mesma produção à condição imprecisa, mas meritória, de arte universal.

Mia Couto (né António Emílio Leite Couto) é, atualmente, o autor com maior visibilidade no universo das letras africanas lusófonas. Natural da cidade da Beira, em Moçambique, costuma ser comparado a outro 
grande autor da língua portuguesa do século XX, o escritor brasileiro João Guimarães Rosa, tanto por tratar de questões relacionadas aos "mistérios" da vida humana, quanto pela inventividade de sua escrita, numa permanente descoberta de novas palavras e estruturas idiomáticas, que resulta, em última instância, de um processo de cruzamento entre o português culto e os vários registros linguísticos empregados pela população local de Moçambique, num inusitado processo de criação, apropriação e renovação do português. A vida do povo moçambicano e sua cultura de modo geral estão representados em sua extensa obra ficcional, na qual não faltam o humor e o trágico, a incorporação da linguagem cotidiana, a inclusão do fantástico e do imaginário, tudo veiculado por meio de uma escritura em que se destaca, como assinalamos há pouco, um intenso trabalho de criatividade linguística.

Autor refinado, tanto no trato da composição quanto no da linguagem, Mia Couto não abandona as tradições populares de seu povo, buscando contemplar aquela moçambicanidade sempre perseguida pelos autores daquela região. Dessa sua idiossincrasia estética disse Patrick Chabal com propriedade:

Mia Couto reflecte no seu trabalho a diversidade do discurso popular. Explora as subtilezas do português moçambicano, falado actualmente em Moçambique, que é distincto do português de Portugal. Enquanto muitos outros escritores moçambicanos ainda usam o português 'clássico', relativamente neutro, Mia Couto está na vanguarda dos que tentam integrar o português de Moçambique na sua escrita (CHABAL, 1994, p. 68).

Buscando vincular, de um lado, aspectos mais propriamente relacionados à língua portuguesa e, de outro lado, elementos da ideologia que perpassa toda sua produção literária - esta última compreensivelmente vinculada ao processo de colonização historicamente vivenciado pelo continente africano -, nosso artigo analisará como a questão linguística se apresenta ao leitor nos contos de Mia Couto. Desse modo, ambas as categorias aqui observadas - a que, por conveniência, chamamos de língua e linguagem - congregam-se no sentido de dar à sua produção ficcional não apenas maior consistência estética, mas também maior alcance ideológico, na medida em que elas se inserem no amplo conjunto de reflexões proposto pelo pós-colonialismo, base teórica do presente artigo.

Assim, em Mia Couto, há que se distinguir uma questão da língua e uma questão da linguagem, ambas inseridas no contexto do pós-colonialismo: a primeira, mais relacionada ao processo de reconstrução idiomática do português no continente africano; a segunda naturalmente vinculada a uma reflexão ideológica que se reflete, metaforicamente, no substrato metalinguístico de sua ficção. 


\section{LÍNGUAELINGUAGEMNOCONTEXTODOPÓS-COLONIALISMO}

Já se tornou um truísmo entre os pesquisadores das áreas da linguística e da literatura o fato de haver uma necessária intersecção entre os conceitos de língua/linguagem e ideologia, já que todos eles atuam em conjunto - pautando-se, em tese, nas relações intercomunicativas -, no sentido de decifrar os meandros da existência humana e analisar sua inserção numa dinâmica social complexa. Esse é, aliás, um fato que pode ser percebido nas considerações que Bakhtin faz acerca da conotação ideológica da palavra:

a palavra é o fenômeno ideológico por excelência. Na realidade toda palavra é absorvida por sua função de signo. A palavra não comporta nada que não seja ligado a essa função, nada que não tenha sido gerado por ela. A palavra é o modo mais puro e sensível de relação social (BAKHTIN, 1988, p. 36).

Este matiz ideológico do discurso linguístico e, por extensão, do literário encontra no solo africano, talvez como em nenhuma outra região, as condições propícias para se desenvolver, renovando um vínculo entre palavra e ideologia que surge como um verdadeiro imperativo. Por isso, pode-se dizer que a opção das ex-colônias de Portugal pela língua portuguesa veio acompanhada pela disposição inalienável a um uso "libertário" do código linguístico, uso que se manifesta em dois sentidos complementares: como oposição/resistência ao poder colonial e como inovação literária a marcar uma identidade cultural lusoafricana. Tal fato faz com que a língua portuguesa não apenas assuma uma participação determinante na construção de um ideário africano, afirmando-se como um idioma de relativa unificação política, mas também atue como discurso formador de povos autônomos, exprimindo - literariamente ou não - sua realidade. Afinal de contas, como já se salientou uma vez, "as visões de mundo não se desvinculam da linguagem, porque a ideologia vista como algo imanente à realidade é indissociável da linguagem. As ideias e, por conseguinte, os discursos são expressões da vida real. A realidade exprime-se pelos discursos" (FIORIN, 1988, p. 33).

Nesse contexto específico, a literatura adquire papel de relevo no processo de afirmação da identidade cultural africana, particularmente em Moçambique e Angola, onde ela conquistou plena representatividade como instrumento de resistência ao poder colonial, sobretudo no que ela apresenta de possibilidades de manipulação criativa a instaurar uma nova realidade cultural. A transgressão do registro-padrão da língua portuguesa, por exemplo, torna-se, desse modo, meio simbólico de veiculação dos anseios libertários da população, sendo utilizada a partir de perspectivas estéticas ideologizadas, já que se volta, a um só tempo, para a manifestação de uma causa revolucionária e afirmação de uma identidade coletiva pós-colonial. Das sociedades emergentes, como são as sociedades moçambicana e angolana e suas congêneres lusoafricanas, surgem estéticas igualmente emer- 
gentes, isto é, expressões artísticas comprometidas com a liberdade política da sociedade em que as mesmas se inserem: são manifestações estéticas em que a função social é, para além de significativa, orgânica, expressando-se, sobretudo, por meio de um sistema estético em que língua e linguagem perfazem um conjunto dinâmico que ultrapassa o mero significado "linguístico" que ele possa sugerir.

Daí o fato de as literaturas que representam as nações lusoafricanas terem na transgressão do código linguístico uma de suas marcas mais sugestivas, tal como o fazem Mia Couto e Luandino Vieira, por exemplo, instaurando uma verdadeira tradição da transgressão. Uma tradição e uma transgressão, diga-se de passagem, que trazem em sua própria razão de ser modos de atuação que servem como paradigma para toda a literatura contemporânea dessas regiões, como já assinalara Manuel Ferreira:

uma das características estilísticas introduzidas por alguns poetas da Mensagem, e que vão ser continuadas pelas gerações seguintes, é não só a integração das palavras da língua-mãe, com relevo para o quimbundo, como também a reapropriação pela escrita da cadeia falada do português dos musseques, e ainda a justaposição de versos do quimbundo e português (FERREIRA, 1987, p. 124).

Por isso, estendendo ainda mais a abrangência do apelo ideológico que a literatura de Mia Couto alcança por meio do processo transgressor aludido, pode-se afirmar que, sem se limitar à dimensão idiomática propriamente dita, seu processo de reescritura da língua portuguesa incide diretamente sobre a própria constituição de uma consciência pós-colonial, servindo assim de substrato ideológico e expressivo ao conceito de moçambicanidade. Com efeito, criador de uma narrativa inovadora, Mia Couto tem produzido um conjunto ficcional que traz como índice mais relevante de sua genialidade artística exatamente uma singular capacidade de reorganização da mundividência moçambicana a partir do processo de recriação linguística presente em toda sua produção literária.

Os estudos relacionados ao pós-colonialismo ganham maior destaque a partir da década de 1980, com as obras de Edward Said e Bill Ashcroft. O primeiro, em seu célebre estudo sobre o orientalismo, buscou analisar o surgimento do Oriente na história das relações europeias como uma construção ideológica, definindo o próprio conceito de orientalismo como um discurso que é, antes, "produzido e existe em um intercâmbio desigual com vários tipos de poder, moldado em certa medida pelo intercâmbio com o poder político [...], com o poder intelectual [...], com o poder cultural [...], com o poder moral" (SAID, 1996, p. 24). Já o segundo, de modo um pouco mais otimista e relacionando a literatura à ideia de resistência o que pode resultar nos conceitos de literatura de resistência ou resistência literária -, lembra que tais conceitos vinculam-se à ideia de uma luta pela libertação nacional, embora não no sentido limitado de militância. Assim, na opinião do autor, em relação à literatura, a ideia de resistência está asso- 
ciada à de transformação, na medida em que o colonizado pode perfeitamente adquirir o capital cultural do colonizador em seu próprio benefício, podendo, inclusive, transformá-lo em uma arma anticolonial:

Despite the power of colonial representation [...], despite the ubiquity and influence of the tropes by which the colonized subjects are marginalized, the colonial subject is never simply a tabula rasa on which colonial discourse can inscribe its representations: his or her engagement of the culture presented as capital may be extremely subtle. This is, in a sense, a key to post-colonial discourse: post-colonial societies can not avoid the effects of the colonization, but those effects need not necessarily be seen as a tragic consequences of cultural subjugation, nor a cultural contamination to be rejected at all costs. The effects of imperial culture are a form of capital - neutral in itself but politically potent in its possibilities - acquired and utilized in the negociation of post-colonial cultural transformation. Ultimately, it is this transformation, rather than a simple opposition, which fulfils many of the goals of resistance (ASHCROFT, 2001, p. 44).

Como estamos sugerindo aqui, tanto a questão da língua quanto a da linguagem inserem-se no universo da teoria do pós-colonialismo, o que parece ser particularmente verdadeiro no contexto dos países africanos, onde, segundo Russel Hamilton, se verificaria um viés contestatório do regime colonial, resultando, no âmbito literário, numa produção reformista e experimentalista, por meio da qual se procura "re-escrever e assim re-inventar a África" (HAMILTON, 1999, p. 16). De fato, essa constante tensão que as sociedades africanas mantiveram e mantêm, historicamente, com o poder colonizador - o que implica, entre outras coisas, como mostra Thomas Bonnici, a crioulização das línguas europeias e uma constante prática contradiscursiva, em relação ao discurso colonial (BONNICI, 2005) - é o que faz das literaturas pós-coloniais manifestações estéticas de resistência ao e de renovação do cânone literário ocidental, contexto em que o trabalho voltado especificamente para um processo de rasura e reelaboração da língua/linguagem do colonizador adquire um valor incontestável. Inventa-se, assim, por meio da literatura pós-colonial produzida no continente africano - em especial a literatura de expressão lusófona - um sujeito e uma nação pós-coloniais que, ultrapassando os limites da discussão dos efeitos da colonização, passa a se referir a "uma ampla gama de experiências políticas, culturais e subjetivas, que se deslocam no tempo (pré e pós-colonial) e se situam em diferentes lugares" (SCHMIDT, 2009, p. 142).

Como poucos autores contemporâneos da literatura africana lusófona em geral e da literatura moçambicana em particular, Mia Couto busca, ao máximo, explorar todas as possibilidades que a língua lhe oferece, a fim de atingir efeitos poéticos e resultados ideológicos até então inalcançáveis. 


\section{LÍNGUA E LINGUAGEM NOS CONTOS DE MIA COUTO}

A questão da língua/linguagem em Mia Couto pode ser apreendida em todos os seus livros, dos teóricos aos ficcionais e, entre estes últimos, tanto nos seus contos quanto em seus romances.

Nos romances, por exemplo, ela surge em toda sua infinita potencialidade, como se observa em O Último Voo do Flamingo (2005), obra que tem no humor uma de suas características mais marcantes, fato que resulta, entre outras coisas, de situações inesperadas, quando não do puro nonsense. Há, evidentemente, um conflito entre o mundo europeu (aqui representado pelo italiano Massimo Risi) e o africano (representado pelo narrador), tema recorrente em Mia Couto, tratado de modo seguro, sem alguns ranços militantes que, eventualmente, poderiam empanar a narrativa. Em meio a essas questões, de fundo mais ideológico, por assim dizer, proliferam criações neológicas, transgressões sintáticas, recursos orais, além de uma série de considerações direta ou indiretamente relacionadas à linguagem propriamente dita: o poder das palavras, a voz dos falecidos, a importância da fala... Em A Varanda do Frangipani (2007[1996]), um dos mais consagrados romances de Mia Couto, destacam-se temas como o conflito entre a tradição nativa africana e a tradição portuguesa, bem como entre o passado - representado pela tradição - e o presente - representando a modernidade. Trabalhando com ciclos distintos (começa com um morto, figurando um ciclo que se fecha; passa ao retorno desse morto à vida, simbolizando um ciclo que se abre; para, finalmente, voltar à condição de morto, num ciclo que volta a se fechar), trata-se de uma narrativa particularmente marcada pelo jogo de identidades (Ermelindo Mucanga/ Izidine Naíta), em que não se dispensa uma reflexão sobre o problema da desterritorialização (como no caso de Domingos Mourão/Xidimingo). A palavra, sobretudo a palavra falada, exerce uma função mítica na história, como ocorre com Navaia Caetano - para quem as pessoas no asilo "vivemos muito oralmente" (COUTO, 2007, p. 26) -, que pede a Ermelindo Mucanga/Izidine Naíta que não escrevesse nada, apenas escutasse sua história. Da mesma forma, a fala, o contar, representa, muitas vezes, uma sentença de morte, além de ser um perigo tanto para quem fala quanto para quem ouve. Finalmente, a questão da linguagem tem ainda um sentido especial na figura da feiticeira Nãozinha, para quem a palavra possuía um valor sobrenatural.

Apesar do potencial de trabalho que os romances sugerem, no que concerne às análises em torno da questão da língua/linguagem, optamos por trabalhar com seus contos, sobretudo pelo caráter sintético que o gênero naturalmente possui (GOTLIB, 1988; SOARES, 1989; TAVARES, 1984), o que tende a tornar mais profícua nossa análise. 


\section{LÍNGUA}

Em relação à língua, já se tornou um lugar comum - embora nunca seja demais voltar ao assunto - assinalar o empenho intenso e constante de Mia Couto na busca de um registro linguístico que exprima, satisfatoriamente, tanto a complexa realidade da sociedade e da história moçambicanas quanto a inapreensível volatilidade do discurso literário. Assim, a partir de um trabalho de reinvenção do código linguístico, o celebrado escritor reconstrói a própria realidade moçambicana, representada, no plano narrativo, como um quadro vivo das tradições, dos conflitos e dos costumes de toda uma nação. Não obstante esse trabalho expressivo de resgate da cultura popular-tradicional de Moçambique, suas principais conquistas estéticas encontram-se no campo da estilística, já que com a prosa ficcional de Mia Couto a literatura moçambicana atinge seu ponto máximo, sobretudo no que diz respeito ao tratamento linguisticamente inovador do texto literário. Tal inovação pode ser verificada tanto no âmbito sintático, levando o autor a promover verdadeira ruptura no encadeamento oracional do português, quanto nos âmbitos morfológico - com sua indefectível criatividade lexical - e fonológico, em que o emprego deliberado de uma linguagem coloquial e o uso de artifícios próprios da oralidade incorporados ao texto escrito fazem de suas transgressões linguísticas uma ocorrência esteticamente programática.

Do ponto de vista fonológico, é, em primeiro lugar, o emprego abundante do relato oral em suas histórias, a fim de promover um processo de recriação da própria linguagem literária, que faz de Mia Couto um dos mais criativos autores da literatura escrita em língua portuguesa. Com muitos diálogos transcritos em sua forma "original", própria da prosódia nativa, Mia Couto apreende a fala local no calor da hora, dando à sua ficção uma dimensão verdadeiramente humana, no rastro do que ressaltou Roland Barthes ao afirmar que "l'appréhension d'un language réel est pour lécrivan l'acte littéraire le plus humain" (BARTHES, 1972, p. 60). Além disso, o uso de termos próprios da linguagem cotidiana pelo autor reforça ainda mais essa sua peculiaridade estética: ao adaptar ao contexto local a linguagem de suas personagens, Mia Couto logra recriar o universo cultural de toda uma nação, revelando, pela ótica do particular, o que ela possui de mais universal e transformando sua literatura num vasto painel humanista destinado à resistência cultural e política de um povo, em que a exemplo do que faz Luandino Vieira em Angola - a noção de identidade nacional não deixa de estar presente (SANTILLI, 1985).

Não apenas no campo da fonologia podem-se apreender as inovações linguageiras de Mia Couto. Também no que concerne ao âmbito morfológico, seu trabalho com a língua portuguesa apura-se e ganha relevo. Trata-se, nesse sentido, das criações neológicas de Mia Couto no plano da renovação lexical, sempre com a intenção de tornar a narrativa mais condizente com a realidade que procura retratar e recriar em suas obras. Processos de formação de palavras como a composição por justaposição 
(logo-logo, aero-anjo) ou por aglutinação (senfins, saltitonto); como a derivação prefixal (desconsegui, imovente, desorfanava, desmarado, desrimou, desabismado, inacreditar, destrapezista), sufixal (pontapesaria, pernação, sapudo, maravilhações, ardível) ou imprópria (milesimamente, dezanovinha, todaviou-se, senão-me, arco-irisca) e muitos outros fazem parte da criatividade linguística de Mia Couto.

No plano sintático-semântico, suas criações ficam por conta de uma série de inovações, que vão da dispensa de conectivos frasais e oracionais (preposições, pronomes, conjunções) a invenções que resultam em efeitos estilísticos diversos, como a ocorrência de inversões entre substantivos e adjetivos (impuros matos, silencioso e adiado ser, culinárias ocupações, obesa moça), uso de palavras com sonoridade parecida (assim postas e não expostas; mais ela versejava menos a veda nela versava; era um dedo sem sexo: só com nexo; um salto na casa, um assalto no peito; graves lei da gravidade; em aparatosa aparição; vez e voz, os olhos e os olhares; sem pertença nem presença; sem fim nem finalidade; nada é repetivel, tudo é repetente?; as tripas já triplas; foi como se o mundo abrisse rochas e rachas; breves são os enquantos, nenhuns os encantos), o emprego de figuras de linguagem (o coração de Gilda se despenteava; seus olhos taquicardíacos; vizinho congênito), tudo concorrendo para a reverberação - por toda sua produção contística - de um singularíssimo efeito estético-estilístico.

Desse modo, tanto do ponto de vista fonológico e morfológico quanto do sintático-semântico, pode-se afirmar que a obra de Mia Couto tem na inovação do código linguístico sua principal marca estilística, fazendo dele um autor em que a ressignificação da língua torna-se elemento estético de primeira grandeza. É o que sugerem Flavio Garcia e Luciana Silva quando, ao considerar Mia Couto um contador de histórias e um escritor que busca renovar a palavra, afirmam:

a origem multifacetada, refletida em sua obra, faz emergir um universo de significações que revolve as palavras, transformando-as para que gerem novos sentidos. Ao ressignificá-las, inovando em relação ao uso da linguagem, ele propõe novos olhares para o que já existe visto desde antes (GARCIA; SILVA, 2012, p. 177).

Visto de outra ótica, não parece exagero afirmar que a literatura de Mia Couto denota - por meio da inovação linguística - uma transgressão do próprio código estético europeu, na medida em que refaz o percurso da escritura literária a partir de outros protocolos artísticos, nos quais está pressuposta a literatura como expressão de uma nova forma a representar um conteúdo. Sua criação linguística faz parte, assim, de um projeto de inovação discursiva, por meio do qual, ao se instaurar um outro discurso literário, inaugura-se uma nova maneira de interpretar a realidade nacional que esse discurso representa. Considerando que, como afirma Maurizzio Gnerre, "a língua dos gramáticos é um produto elaborado que tem a função de ser uma norma imposta sobre a diversidade” (GNERRE, 1987, p. 10), 
Mia Couto opta exatamente por romper com essa espécie de condicionamento linguístico, no qual a língua exemplar torna-se modelo ideal de uso e a norma gramatical a única referência válida para a escrita. Daí o emprego de um código linguístico "mestiço", mesclado por regionalismos e adaptado à dicção sintaticamente aglutinante dos falares locais de Moçambique, tudo esteticamente reestruturado a partir da perspectiva literária que tem na criatividade linguística sua tônica.

Esse movimento tem uma clara conotação ideológica, vinculando-se, facilmente, à teoria do pós-colonialismo, como sugerimos de início. Assim, na medida em que o pós-colonialismo se relaciona não apenas com o contexto histórico da colonização europeia do continente africano, mas sobretudo com as práticas discursivas que atuam como substrato desse contexto, percebe-se em Mia Couto - por meio de um discurso de resistência, de um processo de "canibalização da língua portuguesa pelo colonizado" (LEITE, 2003, p. 13) - uma concessão deliberada ao gesto pós-colonialista que, no universo específico de sua literatura, torna a palavra um autêntico "instrumento de afirmação dos povos de nações lusófonas" (BASTOS; BRITO, 2011, p. 151).

\section{LINGUAGEM}

Em relação à linguagem, aqui entendida como uma categoria que não se limita apenas à configuração gramatical do idioma, mas a uma série de elementos e atitudes vinculados a um sentido mais amplo do registro linguístico, pode-se dizer que duas perspectivas se destacam no processo coutiano de construção de um discurso literário: a busca recorrente do sentido mítico da palavra e a revelação intencional do poder que a palavra concentra em si. Na verdade, há, em Mia Couto, um verdadeiro equilíbrio entre o sentido mítico da palavra - que leva sua literatura para o campo da ficção, vinculando-a ao ato de narrar - e o sentido realista da palavra - que a retorna para a realidade, vinculando-a ao poder. Ambos os sentidos inserem-se no plano da teoria do pós-colonialismo, na medida em que o autor moçambicano - a exemplo de outros autores de língua portuguesa, como Luís Bernardo Honwana, Manuel Rui, Ungulani Ba Ka Khosa, Luandino Vieira - atuam, como defende Niyi Afolabi, no sentido de regenerar o processo de degenerescência da identidade cultural dos povos africanos, promovido pelo sistema colonialista português, processo realizado durante o período pós-colonialista: “apoiando-se em vários modos de subversão, os autores recuperam os valores culturais degenerados pelo colonialismo português nos seus textos enquanto nas obras mais recentes, ridicularizam a corrupção e a violência da condição pós-independência” (AFOLABI, 1997, p. 28).

Com efeito, o tratamento dado pelo escritor moçambicano à linguagem torna sua dicção um discurso não apenas exemplar do ponto de vista estético, mas sobretudo combativo do ponto de vista ideológico. Em Cada homem é uma raça (2013[1998]), por exemplo, ao lado de transgres- 
sões gramaticais e uma prosa poética carregada de metáforas e outras figuras de linguagem, contos marcados por conflitos intimistas ("Rosa Caramela") misturam-se a outros que espelham problemas de natureza racial e afins ("A princesa russa”). Neles, tanto o sentido mítico da palavra quanto a linguagem como poder convivem, plenamente, no plano da narrativa. $\mathrm{O}$ mesmo se pode falar de seus contos de estreia, no livro Vozes Anoitecidas (2013[1987]), em que tudo o que aqui foi dito ganha contornos ainda mais trágicos.

Esse sentido mítico da palavra, a que nos referimos, contudo, surge de modo mais evidente nos contos de Estórias abensonhadas (2012[1994]) e nos de O fio das missangas (2009[2004]). Com efeito, em Estórias abensonhadas deparamo-nos com narrativas que parecem nascer da própria vivência do povo moçambicano, resgatando o sentido mais sagrado da linguagem, descolando-a da crua e insensível realidade, a fim de lhe conferir um sentido sublime, um estatuto de ficção. Ali, a palavra torna-se imagem, voz plena, estória, numa tensão dialética entre verdade e ficção, como se afirma no início de um de seus contos: "Toda a estória se quer fingir verdade. Mas a palavra é um fumo, leve de mais para se prender na vigente realidade. Toda a verdade aspira ser estória. Os factos sonham ser palavras, perfumes fugindo do mundo" (COUTO, 2012, p. 47).

Em O fio das missangas, a relação que as personagens de suas estórias estabelecem com a palavra é, ao mesmo tempo, uma relação de distância e de descoberta: não é o emissor que fala, mas ele é falado, atuando primeiro - numa autêntica inversão de sentido das funções da linguagem como receptor da mensagem: "as palavras desprendem-se de mim" (COUTO, 2009, p. 23), afirma a protagonista de um dos contos. Mesmo assim, a fala tem seus segredos, seus impedimentos, seus silêncios constrangidos e constrangedores, ora exigidos, ora deliberados. Em outro de seus contos, por exemplo, a única permissão que é dada à fala é aquela que a vincula ao contar uma história, permissão dada mesmo a quem, tecnicamente, não fala: "minha mãe, que é muda, que conte" (COUTO, 2009, p. 38). É que no universo mítico de Mia Couto o contar histórias faz parte da própria essência do ser humano, da vida mesma de cada um.

Em Mia Couto, a palavra adquire um peso mítico, um valor quase sagrado, pois, por meio dela, mundos submersos são revelados, segredos e mistérios são desvendados, lembranças perdidas no tempo são resgatadas. Essa realidade premente de sua poética exprime-se em algumas passagens de seus contos, tanto naquelas em que a magia da palavra faz parte do tecido narrativo quanto naquelas em que ela é tema/motivo da própria narrativa. É a narradora do conto "A despedideira" quem expõe essa lógica cerrada, ao afirmar peremptória e reveladoramente:

Quando ele me dirigiu a palavra nesse primeiríssimo dia, dei conta de que, até então, nunca eu tinha falado com ninguém. O que havia feito era negociar palavra, em negoceio de sentimento. Falar é outra coisa, é essa ponte sagrada em que 
ficamos pendentes, suspensos sobre o abismo. Falar é outra coisa, vos digo. Dessa vez, com esse homem, na palavra eu me divinizei. Como perfume em que perdesse minha própria aparência. Me solvia na fala, insubstanciada (COUTO, 2009, p. 52).

Assim, seus contos - como de resto toda sua produção literária - carregados de uma poética simbologia, conformada por meio de mitos e legendas, crenças e visões sobrenaturais, fatos e lembranças que se multiplicam, fundem-se num indescritível painel de imagens sensíveis, levando o autor a trabalhar a fundo o que aqui chamamos de o sentido mítico das palavras.

Como dissemos, porém, há outra força que move - no que concerne ao universo da linguagem - os contos de Mia Couto: trata-se, agora, da ideia de poder da palavra, que, não raramente, se traduz numa tensa relação dialética: a oposição, recorrente em sua ficção, entre a fala e o silêncio, como se falar e calar fossem, no final das contas, faces de uma mesma moeda.

Desse modo, mais do que uma narrativa do falar, seus contos afirmam-se, muitas vezes, como narrativas do calar, numa profusão de imagens em que personagens ora estão indiscriminadamente fadadas ao silêncio ("a mãe era muda, a sua voz esquecera de nascer") (COUTO, 2009, p. 33), ora demonstram, simplesmente, uma resignação que, não obstante, manifesta-se, ainda uma vez, pela ausência da palavra. Nesse contexto, há que se observar, está implicada uma evidente questão de poder: "no capítulo das falas, tinha a sua razão: nós, pobres, devíamos alargar a garganta não para falar, mas para melhor engolir sapos" (COUTO, 2009, p. 34). Mas, inesperadamente, é também no contexto específico da vinculação entre $p a$ lavra e poder que o calar pode até mesmo adquirir um sentido de resistência, como se constata em "O adiado avô":

Curioso: um regime inteiro para não deixar nunca o povo falar e a ele ameaçavam para que não ficasse calado. E aquilo lhe dava um tal sabor de poder que ele se amarrou no silêncio. E foram insultos. Foram pancadas. E foi prisão. Ele entre os muitos cativos por falarem de mais: o único que pagava por não abrir a boca (COUTO, 2009, p. 34).

É que em Mia Couto não surpreendem as opções feitas pelo calar diante de situações extremas, ora de risco, ora de desespero ("Prefiro o silêncio, que condiz melhor com a minha alma”) (COUTO, 2009, p. 22), levando a questão da linguagem a ser colocada no justo entreato da fala e do silêncio.

Mas a relação da linguagem com o poder, no escritor moçambicano, não se limita à tensão acima apontada. Talvez ela se revele (e se resolva) melhor - podendo, assim, ser mais bem compreendida - no contexto das relações pós-coloniais. Há, nesse âmbito, uma discussão que, seguramente, toca em cheio o sentido da linguagem (e, por extensão, da literatura) nos 
países africanos independentes: subverter a linguagem do colonizador, no plano narrativo, como o faz Mia Couto, é, com efeito, uma atitude revolucionária, para retomarmos um conceito próprio do contexto das lutas de libertação colonial, até porque, como registra o próprio escritor em algumas de suas narrativas, não é possível desvincular os conceitos de idioma e de poder, que - no âmbito mais específico da colonização - adquirem um sentido muito mais denso e complexo do que o habitual. Veja-se, por exemplo, a passagem em que o pai do protagonista do conto "O nome gordo de Isadorangela", ao visitar, juntamente com o filho, a casa do presidente da câmara, Dr. Osório Caldas, e após sentenciar que "nós, sendo mulatos, tínhamos sorte em receber a simpatia do chefe", alerta o filho - lançando mão de "um português que [ele] nunca escutara" -, de forma peremptória e ameaçadora, para que "puxasse lustro ao [seu] melhor lusitano idioma." (COUTO, 2009, p. 60/61)

Trata-se, nesse contexto, da exposição de um embate em que a linguagem torna-se o elemento diferencial: quem domina o português padrão - índice e meio de ascensão social - tem o domínio do poder local; mas é exatamente no domínio desse registro, ao desvirtualizá-lo, que a liberdade pode ser alcançada e os índices de poder, invertidos. É o que, em resumo, busca fazer Mia Couto ao criar uma literatura escrita num idioma que, no limite, é e não é o português, na medida exata em que, partindo de um registro- padrão do idioma, ataca-o em seu flanco, a fim de moldá-lo à realidade moçambicana que narra e pela qual, no final das contas, é igualmente narrado. Assim, consciente de que linguagem e poder caminham pari passu, o autor lança mão de uma série de recursos linguísticos que - por serem próprios de um pensar local, de um modo de ser moçambicano - interpõe-se nos meandros do embate entre colonizados e colonizadores, reverberando na própria linguagem. Já não se trata mais de uma luta física, corpórea, entre polos de uma mesma lógica historicamente forjada (o colonialismo), mas de um confronto mais sutil, que se dá no âmbito discursivo-idiomático: o idioma do colonizador é, desse modo, transgredido, transformado, rasurado para que, de seus escombros, outro seja construído, sempre tomando como ponto de partida uma outra disposição ontológica e social. Essa luta contra a violência de um idioma único ("Venâncio estava na violência como quem não sai do seu idioma” (COUTO, 2009, p. 70), transposto e imposto por elementos exógenos, representa bem o "projeto" literário de Mia Couto, transgressor consciente do idioma do colonizador, no qual procura inscrever uma marca da diferença (COUTO, 2014).

Criando assim uma verdadeira prosa poética, o escritor moçambicano não apenas revitaliza o português, mas o reinventa. De fato, nas palavras de Carmen Tindó Secco, Mia Couto, além de reinventar esse idioma, leva-o, "pela morfologia e sintaxe contaminadas por construções modificadas pelos falares moçambicanos, a expressar as marcas multiculturais presentes no imaginário linguístico do país" (SECCO, 1998, p. 161). Por isso, não é difícil encontrar em seus contos, uma verdadeira reflexão meta- 
linguística, com implicações ideológicas várias. É o caso, por exemplo, no conto "O perfume", de suas Estórias Abensonhadas, de Glória, que vincula sua histórica condição de dependência ontológica e social à questão da linguagem: "livre? Era palavra que parecia de outra língua. Só de a soletrar sentia vergonha..." (COUTO, 2012, p. 32). Desse modo, entre a palavra e a coisa que ela representa, há toda uma história de opressão que marca a vivência da protagonista, facilmente identificada com a história de opressão do próprio continente africano, além da opressão de gênero, na medida em que o poder que o homem detém sobre a mulher não se manifesta apenas nas relações sociais cotidianas, mas principalmente no fato de ele, como extensão desse poder autoconferido, tomar para si a palavra, como se percebe nessa emblemática afirmação da, sugestivamente, não identificada mulher do régulo de Namarói: "o que vou contar me foi passado em sonho pelos antepassados. Não fosse isso nunca eu poderia falar. Sou mulher, preciso autorização para ter palavra” (COUTO, 2012, p. 115).

Há, finalmente, em Mia Couto, um aspecto de seu discurso literário que diz respeito ao mesmo tempo à forma como autor trata a língua e as discussões em torno da linguagem em seus textos ficcionais: é a questão da oralidade. A oralidade, no autor, está diretamente vinculada ao conto, gênero que elegemos aqui como objeto de análise dentro de sua diversificada produção ficcional. De fato, como afirma Ítalo Ogliari, o conto, enquanto arte de narrar, pode ser considerado "o gênero mais antigo de todos, originado da fábula, da oralidade, do simples ato de reunir as pessoas e de contar algo" (OGLIARI, 2012, p. 61, grifo meu).

A presença intensa da oralidade pode ser constatada na maioria dos contos de Mia Couto. Afirmando possuir, sua literatura, um compromisso histórico real, Hélio Rodrigues Júnior destaca, contudo, o uso de marcas oralizantes na narrativa coutiana, "subvertendo de modo intencional e esclarecido a língua portuguesa, servindo-se dela como instrumento para alcançar o objetivo de exprimir a sua sensibilidade com que apreende o sentir e a vivência moçambicana" (RODRIGUES JÚNIOR, 2013, p. 19). É, portanto, na questão da oralidade que Mia Couto encontra o verdadeiro equilíbrio entre língua e linguagem em sua produção ficcional, na medida em que ela tanto diz respeito ao modo como uma articulação frásica e/ ou uma configuração gramatical é elaborada/utilizada (língua) quanto se refere à escolha feita pelo autor de um determinado registro linguístico, o que, no caso específico do texto literário, pressupõe uma opção ideológica (linguagem). Com efeito, ao buscar um ponto de equilíbrio de sua narrativa por meio do recurso da oralidade, Mia Couto não apenas revela a importância dos falares locais, mas também denuncia a cultura grafocêntrica representada por um português depurado pelas elites colonizadoras. Essa é, por exemplo, a denúncia que o autor faz ao afirmar que

a mais importante linha divisória em Moçambique não é tanto a fronteira que separa analfabetos e alfabetizados, mas a fronteira entre a lógica da escrita e a lógica da oralidade. 
A maioria absoluta dos 20 milhões de moçambicanos vive e funciona num tipo de racionalidade que tem pouco a ver com o universo urbano. Mas em Moçambique, como no resto do mundo, a lógica da escrita instalou-se com absoluta hegemonia (COUTO, 2011, p. 102).

Desse modo, essa "cultura que sobrevive à margem da escrita" (COUTO, 2011, p. 180), que é a oralidade, é um dos fundamentos estéticos - e, nesse caso, também políticos - da prosa de ficção de Mia Couto. Faz parte desse universo mítico e diversificado que encontramos em sua literatura, quase sempre vinculado à noção de moçambicanidade a que já nos referimos e como reitera, ainda uma vez, Pires Laranjeira, para quem suas narrativas "colocam em situação de exposição, confronto e análise as várias culturas e crenças do homem moçambicano" (LARANJEIRA, 1995, p. 312).

\section{CONSIDERAÇÕES FINAIS}

Tudo o que aqui expusemos tem relação direta, como estamos salientando desde o início, com a perspectiva pós-colonial, presente nas linhas e nas entrelinhas do tecido narrativo de Mia Couto. Realizando um estudo comparativo entre a ficção de Milton Hatoum e de Mia Couto, por exemplo, Vera Maquêa destaca precisamente o caráter poético da escrita deste último, fazendo ainda considerações sobre seu vínculo com questões históricas próprias da realidade de Moçambique nos seguintes termos:

falar a língua do colonizador e dizer a sua própria sempre se constituiu no grande desafio para a formação das literaturas nacionais, mas foi ao mesmo tempo a condenação e a redenção dos países colonizados pela Europa portuguesa [...] a força da escrita de Mia Couto, que a torna tonicamente singular, é a perfeita conjunção entre o conteúdo humano expresso e a percepção da língua que se junta à experiência histórica. A diversidade cultura e linguística existente em Moçambique, implicando variações no próprio português, convida a literatura - ou a provoca - a discutir a dimensão política do convívio com o múltiplo (MAQUÊA, 2008, p. 169).

É exatamente dessa dimensão política de sua escrita que estamos falando quando a vinculamos ao universo teórico do pós-colonialismo. Por isso, insistimos: em Mia Couto, a questão linguística relaciona-se diretamente a um complexo processo de construção identitária, já que é por meio desse substrato linguístico - que envolve, a um só tempo, as noções fluidas de língua materna, de língua de cultura, de língua transplantada etc. - que as identidades se perfazem no contexto histórico de Moçambique, em particular, e da África lusófona, em geral. Nesse sentido, o trabalho minucioso e criativo de reconstrução estética do padrão linguístico do português moçambicano passa necessariamente pelo reconhecimento dos limites e das potencialidades da linguagem, encontrando seu sentido maior na necessidade de, por meio da criação linguística, re-criar identidades sequestradas por um longo, avassalador e cruel processo de colonização. 
Criar uma palavra nova, nesse sentido, não deve ser visto apenas como um ingênuo exercício de criação neológica, desvinculado de outras práticas histórica e ideologicamente construídas, mas como um ato consciente de transformação de uma realidade local que responde - simbólica e factualmente - aos anseios de um povo em se ver representado também em sua maneira de interpretar o mundo à sua volta e se expressar.

Não existe imunidade cultural, já afirmou uma vez Marc Augé, ao estudar, pela perspectiva da cultura, a relação entre indivíduo e sociedade (AUGÉ, 1996); do mesmo modo e com maior razão, diríamos nós, não existe imunidade histórica: a história só se justifica plenamente quando incorpora em sua prática (ou em uma epistemologia, metodologia, axiologia etc.) o humano, sem o qual perde seu sentido. Reconstruir a linguagem a partir das injunções históricas determinadas pelo processo colonizador é incorporar o humano na história, tornando, pela assunção de uma linguagem que $o$ identifica e com o qual ele se identifica, o sujeito de sua própria história ou, em termos de criação literária, proposto por Mia Couto, de sua própria estória.

Para o autor moçambicano, o processo de colonização não apenas impõe ao colonizado um outro modo de falar - vale dizer, de utilizar-se da linguagem verbal, ideia que, nesse contexto, corresponde a uma outra língua -, mas atua também no sentido de sequestrar ao colonizado a possibilidade e o direito de narrar, de contar histórias, as suas histórias: “o mesmo processo que empobreceu o meu continente está, afinal, castrando a nossa condição comum e universal de criadores de histórias" (COUTO, 2011, p. 13). Instaura-se, assim, no continente africano como na literatura ali produzida - em especial, na produção ficcional de Mia Couto - uma constante luta para que a palavra não se torne, no final, apenas um longo e inextricável silêncio.

Portanto, a questão da linguagem, em Mia Couto, guarda em si mesma, como vimos antes, um complexo vínculo com o poder, no contexto pós-colonial; e com a manutenção - mesmo após o período revolucionário - de uma colonização de fato, a situação torna-se ainda mais complicada, já que, mesmo depois da independência, sempre sobram os resquícios, sejam eles materiais (a própria língua portuguesa), sejam eles ideológicos (o poder que o domínio dessa língua representa). Trata-se, aliás, de um domínio que, no âmbito do imaginário popular, ultrapassa os próprios limites terrenos da realidade, interferindo no âmbito metafísico da religião. É por isso que, ao questionar a forma como se devia dar a entrada no céu, o narrador do conto homônimo afirma:

Depois veja: eu não falo inglês. Mesmo em português, eu só rabisco fora da cartilha. Já estou a ver lá o letreiro, ao jeito dos filmes: welcome to paradise! E não mais saberei ler. Bem poderão me conceder a palavra. É como dar um alto-falante a um mudo (COUTO, 2009, p. 78). 
Conceder a palavra, na situação explicitada, torna-se inócuo, pois se trata de uma concessão pro forma, feita apenas para cumprir regras e protocolos, uma vez que de nada adianta oferecer um instrumento sem que lhe sejam oferecidas também as condições para utilizá-lo. Língua transplantada, no contexto da colonização, o português revela-se, assim, um idioma artificial, mais um instrumento de exclusão do que uma maneira de ingresso no mundo dos direitos, distorção que só poderia ser corrigida por meio de uma efetiva política linguística. Na literatura, pelo menos, Mia Couto desfaz essa distorção por meio de um "idioma” que, efetivamente, resgata não apenas o modo de falar do homem moçambicano, mas principalmente seu modo de ser: sua cultura, sua personalidade, sua religião. Torna, assim, o seu "rabisco fora da cartilha" num riscado dentro da existência...

\section{REFERÊNCIAS BIBLIOGRÁFICAS}

AFOLABI, Niyi. Uma Gaiola de Ouro: A Problemática da Regeneração na Literatura Africana de Língua Portuguesa. África. Revista do Centro de Estudos Africanos. Universidade de São Paulo, São Paulo, No. 20-21: $27-$ 41, 1997-1998.

ASHCROFT, Bill. Post-Colonial Transformation. London/New York: Routledge, 2001.

AUGÉ, Marc. El sentido de los otros. Actualidad de la antropología. Paidós: Barcelona, 1996.

BAKHTIN, Mikhail. Marxismo e Filosofia da Linguagem. Problemas Fundamentais do Método Sociológico na Ciência da Linguagem. São Paulo: Hucitec, 1988.

BARTHES, Roland. Le Degré Zero de l'Écriture. Paris: Seuil, 1972.

BASTOS, Neusa Barbosa; BRITO, Regina Helena Pires de. Mia Couto: 'somando colorações' no vocabulário da lusofonia. Matraga, Rio de Janeiro, Vol. 18, No. 28: 143-157, jan.-jun. 2011.

BONNICI, Thomas. Avanços e ambiguidades do pós-colonialismo no limiar do século 21. Légua é meia: revista de literatura e diversidade cultural. Feira de Santana, Universidade Federal de Feira de Santana, Vol. 4, No. 03: 186-202, 2005.

CHABAL, Patrick. Vozes Moçambicanas. Literatura e Nacionalidade. Lisboa: Veja, 1994.

COUTO, Mia. O Último Vôo do Flamingo. São Paulo: Companhia das Letras, 2005.

. A Varanda do Frangipani. São Paulo: Companhia das Letras, 2007. 
. O Fio das Missangas. São Paulo: Companhia das Letras, 2009. . E se Obama fosse Africano? São Paulo: Companhia das Letras, 2011.

. Estórias Abensonhadas. São Paulo: Companhia das Letras, 2012.

. Vozes Anoitecidas. São Paulo: Companhia das Letras, 2013.

. Cada Homem é uma Raça. São Paulo: Companhia das Letras, 2013.

- Mia Couto: o rico contador de histórias (Entrevista por Bruno Garcia, Cristiane Nascimento e Joice Santos). Revista de História da Biblioteca Nacional, Rio de Janeiro, Ano 9, No. 101: 54-59, Fev. 2014.

FERREIRA, Manuel. Literaturas Africanas de Expressão Portuguesa. São Paulo: Ática, 1987.

FIORIN, José Luiz. Linguagem e Ideologia. São Paulo: Ática, 1988.

GARCIA, Flavio; SILVA, Luciana Morais da. Mia Couto: conceitos e sentidos de uma composição híbrida, entre o literal e o literário. Nonada. Letras em Revista, Porto Alegre, Ano 15, No. 19: 171-181, 2012.

GNERRE, Maurizzio. Linguagem, Escrita e Poder. São Paulo: Martins Fontes, 1987.

GOTLIB, Nádia Battella. Teoria do Conto. São Paulo: Ática, 1988.

HAMILTON, Russel G. A literatura dos PALOP e a Teoria Pós-Colonial. Via Atlântica. São Paulo, No. 03: 12-22, Dez. 1999.

LARANJEIRA, Pires. Mia Couto, sonhador de verdades, inventor de lembranças. Em seu Literaturas Africanas de Expressão Portuguesa. Lisboa, Universidade Aberta, 1995, p. 310-318.

- As Literaturas Africanas de Língua Portuguesa - Identidade e Autonomia Scripta, Belo Horizonte, Vol. 03, No. 06: 237-244, 2000.

LEITE, Ana Mafalda. Literaturas Africanas e Formulações Pós-Coloniais. Maputo: Imprensa Universitária / Universidade Eduardo Mondlane, 2003.

OGLIARI, Ítalo. A poética do conto pós-moderno e a situação do gênero no Brasil. Rio de Janeiro: 7Letras, 2012.

MAQUÊA, Vera. A tradução do impossível: Milton Hatoum e Mia Couto. In: SILVA, Agnaldo Rodrigues da (org.). Diálogos Literários. Literatura, Comparativismo e Ensino. São Paulo, Ateliê, 2008, p. 145-178.

RODRIGUES JÚNIOR, Hélios. Guimarães Rosa e Mia Couto: contornos da dimensão humana no universo da lusofonia. Verbum - Cadernos 
de Pós-Graduação. Pontifícia Universidade Católica de São Paulo, São Paulo, No. 05: 16-26, 2013.

SAID, Edward. Orientalismo. O Oriente como Invenção do Ocidente. São Paulo: Companhia das Letras, 1996.

SANTILLI, Maria Aparecida. Africanidade. Contornos Literários. São Paulo: Ática, 1985.

SCHMIDT, Simone Pereira. Onde está o sujeito pós-colonial? (Algumas reflexões sobre o espaço e a condição pós-colonial na literatura angolana). Abril. Revista do Núcleo de Estudos de Literatura Portuguesa e Africana da UFF, Niterói, Vol. 2, No. 2: 136-147, Abr. 2009.

SECCO, Carmen Lúcia Tindó Ribeiro. O ar, as águas e os sonhos no universo poético de Mia Couto. Gragoatá. Revista do Instituto de Letras, Rio de Janeiro, Universidade Federal Fluminense, No. 05: 159-169, 2o. sem. 1998.

SOARES, Angélica. Gêneros Literários. São Paulo: Ática, 1989.

TAVARES, Hênio Último da Cunha. Teoria Literária. Belo Horizonte: Itatiaia, 1984.

Recebido para publicação em 31/05/2017

Aprovado em 10/09/2017

\section{NOTAS}

1 Doutor em Letras Clássicas e Vernáculas, pela Universidade de São Paulo. Professor do Programa de Mestrado e Doutorado em Educação, na Universidade Nove de Julho (São Paulo). Autor de livros e artigos em periódicos nacionais e internacionais. maurisil@ gmail.com 